\title{
Exceptional cameral deposits in a sublethally injured Carboniferous orthoconic nautiloid from the Buckhorn Asphalt Lagerstätte in Oklahoma, USA
}

\author{
Barbara Seuss, Royal H. Mapes, Christian Klug, and Alexander Nützel \\ Acta Palaeontologica Polonica 57 (2), 2012: 375-390 doi: http://dx.doi.org/10.4202/app.2011.0008
}

The cameral and intrasiphonal deposits of a Pennsylvanian straight nautiloid (Pseudorthoceratidae) are studied in order to understand the formation of these deposits. The specimens from the Buckhorn Asphalt deposit (Oklahoma) are exceptionally preserved including original aragonite and microstructures. The specimen investigated survived a predation attempt and shows bite marks on the phragmocone. This is the second report of an ectocochleate cephalopod and first report of an orthoconic nautiloid which survived massive damage of conch and siphuncle. For the first time, a high-magnesium calcitic mineralogy of cameral deposits is documented. These deposits were formed in alternation with aragonite in a chamber which was perforated during the unsuccessful predation attempt. The animal formed the chamber deposits throughout its entire lifetime and the siphuncle played a major role in formation of the cameral deposits.

Key words: Nautiloidea, Pseudorthoceratidae, predation, sublethal damage, cameral deposits, high Mg-calcite (HMC), Carboniferous, Buckhorn Asphalt, Oklahoma, North America.

Barbara Seuss [barbara.seuss@gzn.uni-erlangen.de], GeoZentrum Nordbayern-Paläoumwelt, University of Erlangen-Nuremberg, Loewenichstraße 28, 91054 Erlangen, Germany and Senckenberg am Meer, Abteilung für Meeresforschung, 26382 Wilhelmshaven, Germany; Royal H. Mapes [mapes@ohio.edu], Department of Geological Sciences, 217A Clippinger Hall, Ohio University, Athens, Ohio-OH 45701, USA; Christian Klug [chklug@pim.uzh.ch], Paläontologisches Institut und Museum, Karl Schmid-Straße 4, 8006 Zürich, Switzerland; Alexander Nützel [a.nuetzel@1rz.uni-muenchen.de], Bayerische Staatssammlung für Paläontologie und Geologie and Department of Earth and Environmental Sciences, Paleontology and Geobiology, Geobio-CenterLMU, Richard-Wagner-Straße 10, 80333 München, Germany. 
Attribution License (for details please see creativecommons.org), which permits unrestricted use, distribution, and reproduction in any medium, provided the original author and source are credited.

Fof Full text $(1.492 .8 \mathrm{kB})$ 